\title{
Reverse Stock Splits: The Fiduciary's Obligations Under State Law
}

\author{
Michael J. Lawson ${ }^{\dagger}$
}

This Comment examines the use of the reverse stock split, especially when combined with a repurchase of the resulting fractional shares, as a vehicle for terminating the equity participation of minority shareholders. The author discusses current statutory approaches to the fiduciary's responsibilities in the reverse split transaction, and argues the inadequacy of present safeguards afforded the minority. He proposes a more rigorous analysis of fiduciary compliance with the norm of ratable shareholder treatment to ensure that shareholder interests are not arbitrarily liquidated by the unilateral action of the board of directors.

Current corporate codes in most jurisdictions empower the corporation, through its board of directors, to create fractional share interests through a reverse stock split. Frequently, the corporation is also granted a statutory option to repurchase outstanding fractional shares for casls or other non-equity consideration in an amount determined unilaterally by the board of directors. In those instances in which the reverse split and repurchase are combined, the transaction can result in the liquidation of the equity interest of shareholders with small holdings. State laws impose only cursory restrictions on the corporation's ability to resort to this two step transaction as a device for purposeful and involuntary termination of minority shareholders' equity participation in the enterprise.

The reverse split and repurchase combination may also prove attractive to a publicly held company as a means for "going private." Companies with assets of one million dollars or more whose shares are held by five liundred or more stockholders and companies whose shares are listed on a national securities exchange are subject to extensive federal securities regulation imposed by the Securities Exchange Act

$\dagger$ B.A. 1972, Stanford University; J.D. 1975, Boalt Hall School of Law.

1. See Address by A.A. Sommer, Jr., Comm'r, S.E.C., [1974-1975 Transfer Binder] CCH FED. SEC. L. REP. If 80,010 (1974).

For a discussion of the "going private" phenomenon, see Comment, 84 YALE L.J. 903 (1975); Borden, Going Private-Old Tort, New Tort or No Tort?, 49 N.Y.U.L. REV. 987 (1974). 
of 1934. ${ }^{2}$ By engaging in a transaction that reduces the number of outstanding shareholders below the threshold which triggers the federal regulatory scheme $(300)^{3}$ or that reduces the number of publicly held shares sufficiently to cause involuntary delisting from a national securities exchange, the corporation inay "go private" and become exempt from many of the strictures on corporate behavior imposed by federal law. Financial costs of compliance with federal securities laws are also eliminated.

Corporations can also realize other advantages froin these two transactions, whether used separately or in combination. Reverse sphits are often motivated by interests germane to the business of the enterprise, such as enhancing the market appeal of shares with an abnormally low market price. Where outstanding fractional shares are repurchased by the issuing corporation, administrative economies nay be achieved through the elimination of small shareholders from the corporate books. Moreover, the repurchase of equity shares may allow the corporation and the remaining stockholders to take advantage of an attractive investment in the corporation's own shares in a temporarily depressed market where the book value of shares exceeds their market value.

The benefits which the corporation may realize as the result of a reverse split and repurchase transaction often are obtained primarily at the expense of the minority stockholder. Despite the fiduciary obligation owed the minority by the corporation, the equity interest of only the minority shareholder is terminated as the result of a repurchase of fractional shares. In addition, the stockholder of a relatively small number of shares may suffer a disproportionately greater loss of investment liquidity as a direct result of the reverse split and repurchase than stockholders with a greater number of shares. Finally, a shareholder whose fractional share is repurchased by the issuing corporation is compelled under the typical repurchase statute to accept for his share interest a cash value determined conclusively and unilaterally by the board of directors.

While the termination of minority shareholder interests may be effectuated in a variety of corporate transactions, this Cominent examines the statutory framework of state law governing the reverse stock split and repurchase combination as a technique for oppression and termination of minority shareholders. A more rigorous scrutinization of the fiduciary responsibilities of the corporation and the board of directors to the minority is proposed as one enforcement mechanism

2. 15 U.S.C. \$§ 78a-78hh-1 (1970).

3. 15 U.S.C. $\$ 78 \mathrm{l}(\mathrm{g})(4)(1970)$. 
to reduce the incidence and severity of minority oppression. Finally, in those instances in which such a repurchase is justifiable, an alternative scheme of valuing repurchased fractional shares is proposed which would serve to assure fair compensation to the selling fractional shareholder.

\section{THE STATUTORY FrameWORK FOR THE REVERSE SPLIT AND REPURCHASE COMBINATION}

The corporation laws of most jurisdictions contain four provisions which can be coinbined by issuers to attempt a freeze out of minority shareholders through a reverse stock sphit and repurchase of fractional shares: (1) a corporation inay amend its articles of incorporation to increase or decrease the authorized number of shares, or to reclassify or cancel all or part of its shares; ${ }^{4}(2)$ a corporation may issue fractional shares, ${ }^{5}$ or the board of directors may in heu thereof pay in cash the fair value of fractional shares, in the same transaction that triggered the fractional share interest; ${ }^{*}$ (3) a corporation nay purchase or otherwise acquire its own shares for the purpose of eliminating fractional shares that are outstanding and that were not hquidated as part of the triggering transaction; ${ }^{\top}$ and (4) a corporation may issue scrip in lieu of fractional shares subject to the condition that the shares for which scrip is exchangeable may be sold by the corporation and the proceeds thereof distributed to the holders of scrip. ${ }^{8}$ The implications of the reverse spht for the minority stockholder vary according to the combination of these powers which the board of directors clooses to utilize.

4. See, e.g., Cal. Corp. Code $\$ 3601$ (West Supp. 1974); Dex. Gen. Corp. Law $\S 242$ (1974); IIL. ANN. STAT. ch. 32, $\$ 157.52-7$ (Smith-Hurd Supp. 1975), amending IIL. ANN. STAT. ch. 32, § 157.52 (Smith-Hurd 1969); ABA MODEL BUS. CoRP. ACT $\$ 58$ (1969 rev.).

5. See, e.g., Del. Gen. Corp. LAW $§ 155$ (1974); N.Y. Bus. Corp. LAw $\$ 509$ (McKinney 1963); Oho Rev. Code ANN. $\$ 1701.24$ (Page 1964); PA. Stat. ANN. tit. 15 , 1608 (1967); ABA Model Bus. CoRP. ACT $\$ 24$ (1969 rev.). But see ConN. GEN. STAT. ANN. $\& 33-346$ (1958) (prohibiting the issuance of fractional shares, but authorizing the issuance of scrip in lieu thereof); VA. CODE ANN. \& 13.1-21 (Supp. 1975) (limiting the issuance of fractional shares to open end investment trusts, but authorizing any corporation to issue scrip instead of fractional share certificates).

6. See, e.g., DeL. Gen. Corp. LAw $§ 155$ (1974); N.Y. Bus. Corp. Law $\$ 509$ (Mckinney 1963); Omo Rev. Code ANN. \$1701.24 (Page 1964); PA. Stat. ANN. tit. 15, §§ 1608, 1702.1(B) (1967); ABA MODEL BUS. CORP. ACT $\$ 24$ (1969 rev.). At least one jurisdiction does not provide for cash payment for fractions of a share. Mass. GEN. LAWS ANN. ch. 156B, \$ 28 (1970).

7. See, e.g., CAL. CoRp. Code $\$ 1706$ (West 1955); Ill. ANN. Stat. ch. 32, § 157.6 (Sinith-Hurd 1969); Del. GEN. CoRP. LAW $\$ 160$ (Supp. 1974); ABA ModEL Bus. CORP. ACT $\$ 6$ (1969 rev.).

8. See, e.g., DEL. GEN. Corp. LAW $\$ 155$ (1974); N.Y. Bus. Corp. LAW $\S 509$ (McKinney 1963); ABA Moded Bus. CORP. ACT $\$ 24$ (1969 rev.). 
When a reverse split and repurcliase is undertaken, the board of directors proposes by resolution to amend the articles of incorporation to reclassify outstanding shares by a reverse stock split. ${ }^{9}$ The excliange ratio to be applied to outstanding slares is unilaterally proposed by the board..$^{10}$ In most states, amendment of the articles in conformity with such board resolutions requires only majority sliareliolder approval unless the articles specify a higher proportion. ${ }^{11}$

Where a purpose of the reverse split is the partial or complete elimination of minority stockholders, the exchange ratio will generally be sufficiently large (for example one new share for one hundred outstanding shares) to reduce many sinall shareholdings to less than one new share. In its nnost extreme form, the board proposes a high exchange ratio tailored strictly to the individual shareholdings of the controlling shareholders. ${ }^{12}$ When applied to all individual shareholdings, this "one share split" allots at least one full share to the dominant shareliolders, while reducing the holdings of all other stockholders to less than one full share. For example, if the three dominant shareholders of a corporation own respectively five thousand, four thousand, and three thousand shares, the board may propose an exchange ratio of one for three thousand, with the result that only these three shareholders will be entitled to a full post-split share interest.

Traditionally, most jurisdictions have authorized corporations to issue certificates for fractions of a share to represent the fractional interests resulting froin sucl transactions. ${ }^{13}$ These fractional shares are typically vested with the same substantive rights attendant to full equity shares for the purposes of voting, dividend declarations, and participation in the distribution of assets at dissolution, but these rights are exercisable only in proportion to the fractional interest. ${ }^{14}$ The admin-

9. See note 4 supra.

10. See, e.g., CAL. CoRp. Code $\$ 1706$ (West 1955); Del. Gen. Corp. LAw $\$$ 160 (1974); Ill. ANN. Stat. ch. 32, § 157.6 (Smith-Hurd Supp. 1975); ABA Model Bus. CORP. ACT $\$ 6$ (1969 rev.).

11. See, e.g., Cal. Corp. CODE $\$ 3632$ (West Supp. 1974); DeL. GEN. Corp. LAW $\S 242$ (c) (1974); N.Y. Bus. CoRP. LAW $\$ 803$ (McKinney 1963); ABA Model Bus. CORP. ACT $\$ 59$ (1969 rev.). A minority of jurisdictions require two-thirds approval for a certificate amendment. See, e.g., OHo REv. CoDE ANN. \$ 1701.71 (Page 1964); MD. Ann. Code art. 23, § 11 (1973); Conn. Gen. Stat. ANn. § 33-360 (1958).

12. For the purposes of this discussion and unless otherwise noted, the terms "controlling shareholders" and "insiders" will refer interchangeably to those persons or corporations which possess the direct or indirect power to determine corporate management and policies. This capability is primarily exercised through the ownership of voting securities, but can also arise by contract, or otherwise.

13. See note 5 supra.

14. The statutes cited in note 4 supra are typical. The issuance of fractional shares generally can include limitations on the substantive rights, if the board of directors so chooses. Unlimited discretion to make such restrictions seems undesirable, 
istrative inconvenience to the corporation in computing dividends and votes on fractional shares, ${ }^{15}$ however, has resulted in widespread legislation providing two alternatives to the issuance of fractional share certificates: the issuance of scrip or warrants and the payment of cash in lieu of fractional shares. ${ }^{18}$

Scrip and warrants preserve a shareholder's proprietary interest in the enterprise, and may be aggregated with other scrip or warrants to a full share interest, exchangeable for a full share certificate. Unlike the fractional share, lowever, scrip and warrants confer no substantive shareholder rights. ${ }^{17}$ The issuance of scrip therefore substantially reduces the administrative intricacies inherent in fractional shares. Nonetheless, many jurisdictions which permit the issuance of scrip in lieu of fractional shares needlessly carry the solution further and provide that outstanding scrip shall be deemed void if not aggregated to a full share interest within a term specified by the board of directors. ${ }^{18}$ Many also allow the corporation, if the scrip issuance is so conditioned, to sell the full shares represented by the scrip, paying the value received to the scripholders proportionately. ${ }^{10}$

A second alternative provided by most statutes is the payment of cash in lieu of fractional shares in an amount roughly equivalent to the proportionate value of a full share. ${ }^{20}$ This cash repurchase may take place contemporaneously with the transaction creating the fractional interest so that there is only a fictional issuance of fractional shares, ${ }^{21}$ or it may occur in a subsequent and independent transaction. ${ }^{22}$ Both forms of repurchase relieve the corporation of the administrative

however, since the corporation could conceivably issue solely restricted fractional shares.

15. See Waring, Fractional Shares Under Stock Dividend Declarations, 44 HARv. L. Rev. 404, 406, 410-11 (1931).

16. See, e.g., Del. Gen. CoRp. LaW \& 155 (1974); N.J. Stat. ANN. \& 14A:7-13 (1968); Pa. Stat. ANn. tit. 15, \&1608 (1967); ABA Model Bus. CoRP. ACT $\S 24$ (1969 rev.).

17. See, e.g., Det. Gen. CoRp. LAW $\S 155$ (1974); N.Y. Bus. CoRp. LaW $\$ 509$ (McKinney 1963); OHIo Rep. Code ANN. \$ 1701.24 (Page 1964); PA. Stat. ANN. tit. 15 , $\$ 1608$ (1967). Such statutes generally deny rights in voting, dividends, and liquidation participation unless otherwise provided by the issuing corporation in the articles of incorporation.

18. See, e.g., Del. Gen. Corp. Law $\$ 155$ (1974); N.J. Stat. ANn. \& 14A:7-13 (1968); N.Y. Bus. CORP. LAW $\S 509$ (McKinney 1963); ABA MOdeL Bus. CoRP. ACT $\$ 24$ (1969 rev.).

19. See, e.g., Ill. ANN. Stat. cl. 32, \& 157.22 (Smith-Hurd Supp. 1975). The time limit and the sale by the corporation of shares exchangeable for scrip nay be combined, as in Teschner v. Chicago Title \& Trust Co., 59 Ill. 2d 452, 322 N.E.2d 54 (1974), discussed in text accompanying notes 23-24 infra.

20. See note 6 supra.

21. Id.

22. See note 7 supra. 
burdens associated with fractional shares. By integrating the repurchase into the triggering transaction, however, the corporation avoids the expense and delay of an actual issuance of fractional shares. In either instance the corporation completely freezes out shareholders whose post-split holdings amount to less than one full share.

Where sale of a fractional interest is not compulsory, the shareholder may be given the option to put up sufficient casli in addition to the fractional interest to aggregate to a full share interest and thereby maintain an equity participation in the enterprise. The amendment to the articles may also, however, restrict the use of cash as a mode of aggregation. Alternatively, it may be possible for the shareholder to aggregate to a full share by purchasing other fractional interests from other shareholders. Since the post-split value of shares is inflated by a figure roughly inverse to the exchange ratio, however, this process of "rounding up" with cash or additional fractional interests to aggregate a full share is likely to require an immediate and substantial financial commitment by the minority shareholder in order to remain in the company. Where shares with a market value of $\$ 5$ each are split in reverse at the ratio of one for fifty, post-split shares could have a value as high as $\$ 250$ each. As a further disincentive to "rounding up," the issuer may offer to repurchase fractional interests for cash at a premium over the current market value of post-split shares. The minority shareholder intent on aggregating is thus forced to match this premium and to reject an economically attractive offer for his own share interest in order to obtain fractional interests held by other shareholders.

The utilization of this statutory matrix to eliminate public shareholders through a reverse split has been upheld recently in Teschner v. Chicago Title \& Trust $\mathrm{Co}^{23}$ The plaintiff in Teschner owned common stock in Chicago Title. In 1969, Lincoln National Corporation inade an attractive exchange offer to shareholders of Chicago Title and eventually obtained in excess of 99.9 percent of Chicago Title's common stock. The plaintiff refused to participate in the exchange offer. As a result of this substantial acquisition, the number of cominon shareholders of the target company was drastically reduced, and Chicago Title stock was delisted from the New York Stock Exchange. In 1971, the board of directors of Chicago Title, now a 99.9 percent subsidiary of Lincoln National, resolved to amend the articles of incorporation to authorize a reverse stock split, to prohibit the issuance of fractional share certificates, and to purchase outstanding fractional share interests for a cash value to be determined solely by the board. The exchange ratio adopted by the board provided that Chicago Title's common stock, in

23. 59 IIl. $2 \mathrm{~d} 452,322$ N.E.2d 54 (1974). 
excess of two million shares with a par value of $\$ 6.66$ each, would be reclassified into approximately 3,700 shares with a par value of $\$ 4,000$ each. The proposed amendment was approved at a shareholder meeting, Lincoln National voting its 99.9 percent interest in favor of the proposal. The plaintiff's shareholdings were reclassified as $63 / 600$ of a share, and the issuer repurchased this outstanding fractional interest for cash. As a result of the transaction, the equity interest of all minority shareholders of Chicago Title was terminated.

In upholding the validity of the reverse split and repurchase of fractional shares, the Illinois Supreme Court emphasized that the transactions were undertaken in literal compliance with a statutory scheme. Accordimgly, it said, a shareholder could not complain of an amendment of the corporate articles within the scope apparently authorized by state law, absent fraud or inadequate valuation of the shares. ${ }^{24}$

\section{II}

\section{Application of a Fiduciary Standard TO THE REVERSE SPLIT}

\section{A. Overview}

An examination of the roles of directors and shareholders under current statutes suggests the absence of any effective internal mechanism through which minority shareholders may deter arbitrary action by management in adopting a reverse split or in valuing shares for repurchase. The initial proposal to undertake a reverse stock split or repurchase fractional shares is largely a matter of internal corporate management within the province of the board of directors. Although the reverse stock split and repurchase transaction does not yet widely enjoy the express legislative sanction for freezing out minority shareholders which some courts credit to the short-form inerger, ${ }^{25}$ the permissive language of virtually all relevant statutes appears to give the corporation, and by implication management, untrammeled discretion to declare a reverse split, to determine the exchange ratio to be apphed to outstanding shares regardless of the severity of the reclassification, to repurchase fractional shares or interests, and to issue scrip or pay cash in lieu of fractional shares. Shareholders, in their capacity as such,

24. Id. at -, 322 N.E.2d at 57.

25. See, e.g., Green v. Santa Fe Industries, Inc., 391 F. Supp. 849 (S.D.N.Y. 1975); Stauffer v. Standard Brands Inc., 41 Del. Ch. 7, 187 A.2d 78 (1962); Willcox v. Stern, 18 N.Y.2d 195, 219 N.E.2d 401, 273 N.Y.S.2d 38 (1966). But see Teschner v. Chicago Title \& Trust Co., 59 Ill. 2 d 452, 322 N.E.2d 54 (1974), where the court analogized the reverse split to a short-form merger for the purpose of eliminating minority sharelıolders. 
have no power to initially propose the action contemplated by the amendment, or to revise the substantive aspects of the board's proposal. Their role is restricted to majority approval or disapproval of a transaction proposed, structured, and preliminarily approved by the board.

It is arguable that the effect of such statutes is to render the reverse split and repurchase prima facie valid, as an appropriate exercise of the board's business judgment. ${ }^{26}$ Some courts substantiate this conclusion through a presumption that the judgment of the board and the majority stockholders is formed in good faith and for a proper purpose. $^{27}$ The practical result may then be to defer to the business judgment of management regarding the propriety of the transaction. This places upon the objecting shareholder the difficult burden of demonstrating that the transaction evidences a breach of the duty of loyalty, rather than an honest error of business judgment. ${ }^{28}$

The business judgment standard may be suitable for review of actions taken by management which have no potential for discriminatory treatınent of shareholders inter se, but it is an inadequate means to check arbitrary action by the board or majority shareholders that turns on the size of individual shareholdings, due to the conflict of interest involved. Redefining the responsibility of insiders in terms of their acknowledged fiduciary obligation to the minority does not necessarily remedy the inadequacies of the business judgment standard: majority shareholders and the board nay satisfy a superficial fiduciary standard where a reverse split and repurchase is applied to all shares without discrimination based on the majority or minority status of the shares involved. This superficially nondiscriminatory transaction, however, generates disparities of treatinent which disproportionately disadvantage small shareholders. ${ }^{29}$ Consequently, courts that intend to afford the full protection to minority interests consonant with the fiduciary obligation should more rigorously analyze the ratability of shareholder treatment and avoidance of discrimination between shareholders

26. See Teschner v. Chicago Title \& Trust Co, 59 III. $2 \mathrm{~d} 452,322$ N.E.2d 54 (1974); Rubel v. Rubel Corp., 25 Misc. $2 d$ 388, 206 N.Y.S.2d 396 (Sup. Ct. 1960); cf. Cheff v. Mathes, 41 Del. Ch. 494, 199 A.2d 548 (Del. 1964) (determination by the board of directors causing the corporation to repurchase its own shares reviewed under the business judgment standard).

27. See, e.g., MacCrone v. American Capital Corp., 51 F. Supp. 462, 466 (D. Del. 1943) (applying Delaware law); Porges v. Vadsco Sales Corp., 27 Del. Ch. 127, 13335, 32 A.2d 148, 151-52 (Del. Ch. 1943); MacFarlane v. North Am. Cement Corp., 16 Del. Ch. 172, 181-83, 157 A. 396, 400 (Del. Ch. 1928). All three cases apply the presumption to merger proposals and corresponding shareholder votes.

28. See MacCrone v. American Capital Corp., 51 F. Supp. 462, 466 (D. Del 1943) (applying Delaware law); cf. Dodd, Purchase and Redemption by a Corporation of Its Own Shares: The Substantive Law, 89 U. PA. L. REv. 697, 704-06 (1941).

29. See text accompanying notes 32-38 infra. 
in reviewing the quality of a fiduciary's performance in a potential freeze out transaction.

\section{B. Obligation of Ratable Shareholder Treatment}

The reverse split and repurchase is a transaction demanding a multi-tiered fiduciary responsibility to treat shareholders equally. Simply put, fiduciaries are prohibited froin favoring certain stockholders over other stockholders of the same corporation. It is one aspect of the fiduciary responsibility that management exercise its powers in a manner that affects all shareholders ratably and that avoids undue discrimination between shareholders. The most obvious fiduciary obligation requires that all shares of the same class be similarly reclassified by a reverse split. Plainly, the board cannot effect an overt dilution of proportionate minority ownership by causing only minority shares to be split in reverse. ${ }^{30}$ Nor may the board cause the corporation to arbitrarily repurchase for cash those fractional interests held by minority shareholders without at the same time taking up pro rata the fractional imterests held by insiders.

Yet fiduciaries do not wholly discharge their responsibility of ratability among shareholders by a superficially evenhanded reclassification and repurchase of shares. The discriminatory nature of a freeze out transaction, in which some shareholders are adversely affected while other are not, requires that a fiduciary analysis should consider the relative adverse effects which a freeze out, particularly in the context of "going private," inay peculiarly inflict upon minority shares.

To the extent that the exchange ratio proposed by the board is primarily tailored to reduce a disproportionate number of minority shareholdings to less than one full share, thereby allowing the corporation to terminate the resulting fractional equity interests by a cash purchase, the conclusion may be drawn that fiduciaries have acted to benefit themselves alone, or at least in a manner detrimental to the minority. A violation of fiduciary duty in this regard is especially egregious in the "one share split," in which the exchange ratio is not designed to promote the proper conduct of the busimess, but instead is geared solely to the individual holdings of the controlling stockholders. Questions regarding fiduciary obligation arise even where the exchange ratio is not so patently discriminatory as in the "one share split." Any drastic reduction in the number of outstanding and publicly held shares may impair the liquidity of a stockholder's investment. ${ }^{81}$ Both the loss of equity and the impairment of hquidity will, often in-

30. Cf. Biltmore Motor Corp. v. Roque, 291 So. $2 d 114$ (Fla. Dist. Ct. App. 1974); Browning v. C \& C Plywood Corp., 248 Ore. 574, 434 P.2d 339 (1967).

31. See text accompanying notes 32-38 infra. 
tentionally, injure the minority shareholder disproportionately. ${ }^{32}$

Granted that there may be legitimate reasons for undertaking a reverse stock split which could justify some discrimination against the small shareholder, the fiduciary nonetheless should be obliged to minimize the potential detriment to the minority while acting to promote valid business objectives. A balance of competing interests should be implicit in the formulation of the exchange ratio, and the board should propose a ratio no greater than that necessary to realize legitimate objectives. The following discussion suggests an approach which reconciles pursuit of these corporate objectives, first, with the adverse impact on liquidity to all shareholders, and, second, with the forced loss of equity by some shareholders.

\section{Reduced Liquidity}

Most freeze out transactions, whether or not utilized for the purpose of "going private," potentially impair the marketability of the stockholder's investment. A reverse stock split directly affects liquidity by drastically reducing the number of salable shares in the marketplace, whether the market is a national exchange, over-the-counter, or face to face..$^{33}$ Prior to a reverse split, a shareholder with 100 shares could sell a portion of his stock and still retain an ownership interest. After a split of one for one liundred, the shareholder may elect to retain sliares which would otherwise be in the market in order to preserve a full share equity interest.

A corollary to the reduction of outstanding sliares is the inflated market value of post-split shares. Where a reverse split is effected with a high exchange ratio, such as one for one hundred, a "megasliare" results with a correspondingly inflated market value of hundreds or thousands of dollars. ${ }^{34}$ An investment of this magnitude is unattractive to many purchasers in the market, and consequently market activity on an exchange or over-the-counter will decrease. ${ }^{35}$ When the reverse

32. Id.

33. Involuntary delisting of shares from the New York Stock Exchange may be triggered by a reduction in the number of publicly held shares to less than 600,000 . Shares held by corporate officers, directors, or their immediate families, and other concentrated holdings of 10 percent or more are excluded in ascertaining the number of publicly-held shares. 2 CCH New YORK STOCK ExCH. GUIDE, $\mid$ 2499.20.

34. In Teschner, the $2,233,321$ outstanding common shares of Chicago Title were reclassified into 3,722 shares. The exchange ratio of one for six hundred resulted in post-split shares with a theoretical market value in excess of $\$ 4,000$ each. The pre-split market value was approximately $\$ 65$ per share. $59 \mathrm{III} .2 \mathrm{~d}$ at -, 322 N.E. $2 \mathrm{~d}$ at 55 .

35. An "abnormally low ... volume of trading" is a criterion which may result in involuntary delisting from the New York Stock Exchange. $2 \mathrm{CCH}$ NEW YORK STOCK Excr. GUIDE, T 2499.10.

Selection of a moderate exchange ratio, on the other hand, could conceivably enhance the market appeal of shares with an abnormally low selling price, such as a fraction of one dollar. 
split is undertaken for the purpose of a freeze out, such an impairment of liquidity tends to serve the freeze out purpose. A shareholder faced with the prospect of an unmarketable imvestment will be inclined to accept a liquid cash offer from the issuer, thereby terminating the equity interest himself. The corporation is thus spared from compelling repurchase of fractional shares in a subsequent transaction.

In the event that the liquidity of all shares, majority and minority alike, is impaired to the same extent, insiders gain no apparent advantage manifesting a breach of fiduciary duty. A mechamical application of the ratability norm does not sufficiently protect the interests and expectations of the minority, however, particularly in a publicly held corporation. Presumably insiders do not take their shares with a view toward speculation and sale in the short term market, but rather tend to hold their shares as a commitinent to the long term prospects of the company. ${ }^{36}$ Some dominant shareholders may in fact be characterized as parties who obtain the bulk of their stock in transactions wholly outside the public market as promoters, incorporators, or purchasers of corporate control from previous controlling shareholders. The temporary loss of liquidity which may be occasioned by a reverse split is not detrimental to the insider for whom marketability is a consideration of only secondary significance. On the other hand, the small shareholder in a publicly lield corporation, and perhaps to a lesser extent in the privately held enterprise, is likely to have acquired an equity interest in the corporation through the market. Unlike the dominant shareholder, the expectations of: the small stockholder are oriented to a greater extent to the market and its short term fluctuations, and not to a long term participation in the corporation. ${ }^{37}$ The ability to return to the market to dispose of shares is an assumption of the utmost importance to the small shareholder. Were it not for this expectation of liquidity, it is probable that the investment would not initially have been undertaken.

Viewed from this perspective, the adverse effect on liquidity resulting from a reverse stock spht operates to particularly disadvantage the minority. When liquidity has been impaired to a substantial degree, it can be argued that management has not discharged its fiduciary obligation to use its ability to control the corporation in a fair, just, and equitable fashion, and in a manner which is not disproportionately detrimental to the minority interest. ${ }^{38}$

36. See Eisenberg, The Legal Role of Shareholders and Management in Modern Corporate Decisionmaking, 57 CALIF. L. REv. 1, 81-86 (1969).

37. Id. at 81-82.

38. See Jones v. H. F. Ahmanson \& Co., 1 Cal. 3d 93, 460 P.2d 464, 81 Cal. Rptr. 592 (1969). 
A separate analysis of fiduciary responsibility can be pursued by viewing the marketability of corporate shares in general as a corporate asset. $^{30}$ Liquidity directly benefits all shareholders and increases the attractiveness of the corporation to outside investors. The controlled deprivation of marketability incident to a freeze out is particularly objectionable in view of management's ability to subsequently return to a more receptive market and revitalize the marketability of shares through a public offering. Manipulation of liquidity through a freeze out places majority shareholders in a position to secure an advantage not otherwise available to all shareholders. As a corporate asset, marketability nay not be encumbered or disposed of by the fiduciary where such action disproportionately prejudices the minority; rather, benefits of the asset must be divided proportionately aniong all stockholders. ${ }^{40}$

Purposeful action by fiduciaries which poses the possibility of involuntary delisting of the corporation's shares from a national securities exchange or from an over-the-counter market may also diminish the value of a corporate asset. ${ }^{41}$ Many advantages accrue to the corporation and shareholders from such a listing, including superior marketability of shares, the increase in market value of shares which may flow from a listing, and the safeguards for responsible inanagement provided by the Securities Exchange Act of $1934^{42}$ and excliange rules.

39. Note, Controlling Stockholders Who Exclude Minority Stockholders from Plan to Create New Market for Stock Violate Fiduciary Duty Owed to Minority, 83 Harv. L. REv. 1904, 1907 (1970); see United Funds, Inc. v. Carter Prod., Inc., [1961-1964 Transfer Binder] CCH Fed. SEC. L. Rep. I 91,288 (Baltimore City Cir. Ct., Md. May 16, 1963); 77 HARv. L. Rev. 757 (1964); 49 VA. L. Rev. 1216 (1963); cf. Jones v. H. F. Ahmanson \& Co., 1 Cal. 3d 93, 115, 117, 460 P.2d 464, 476, 478, 81 Cal. Rptr. $592,604,606$ (1969). Though framed in terms of harm to the corporation, the analysis has often been utilized to allow judicial intervention where the primary harm is to shareholders. See, e.g., Diamond v. Oreamuno, 24 N.Y.2d 494, 248 N.E.2d 910,301 N.Y.S.2d 78 (1969). While this may have the merit of allowing derivative suits on the cause of action, it should not obscure the fiduciary obligation underlying the result. The court in Jones acknowledged this analysis, allowing a personal action by a shareholder for the fiduciary's abuse of corporate control which disadvantaged the minority. Nonetheless, the court apparently was constrained to use corporate asset language in reaching its result. 1 Cal. 3d at 117, 460 P.2d at 478, 81 Cal. Rptr. at 606.

40. Jones v. H. F. Ahmanson \& Co., 1 Cal. 3d 93, 117-18, 460 P.2d 464, 478, 81 Cal. Rptr. 592, 606 (1969), citing Perlman v. Feldmann, 219 F.2d 173 (2d Cir.), cert. denied, 349 U.S. 952 (1955).

41. United Funds, Inc. v. Carter Prod., Inc., [1961-1964 Transfer Binder] CCH Fed. SeC. L. Rep. I 91,288 at 94,290 (Baltimore City Cir. Ct., Md. May 16, 1963); 77 HARV. L. REv. 757 (1964); 49 VA. L. Rev. 1216 (1963). Those actions by the issuer which may lead to an involuntary delisting from the New York Stock Exchange are set forth in 2 CCH NEw YORK STOCK EXCH. GUIDE, TाT 2499.10-.20.

42. 15 U.S.C. $\$ \$ 78 \mathrm{a}-78 \mathrm{hh}-1$ (1970). The loss of the shareholder protections afforded under federal law and exchange rules was reviewed under the corporate asset analysis in United Funds, Inc. v. Carter Prod., Inc., [1961-1964 Transfer Binder] CCH 
While "going private" transactions affect all shareholders in this regard, whether majority or minority, the fiduciary's action is significantly more damaging to the expectations and interests of the minority because the majority retains the option to return to the exchange and because, in any case, the majority will presumably protect its own interests.

\section{Loss of Equity}

Where the board of directors proposes to issue fractional share certificates to accommodate the fractional interests resulting from a reverse stock spht, the ownership by all shareholders of the same pro rata equity interest in the corporation inter se is preserved. Assuming no subsequent corporate repurchase of outstanding fractional shares for cash, the transaction terminates no shareholder's status as such. Although legitimate questions remain in a "going private" or other freeze out transaction regarding the formulation of the exchange ratio and its effect on the hquidity of shares, no potential exists for a discriminatory sequestration of the assets for the benefit of some shareholders to the exclusion of others.

The opposite extreme occurs when the board proposes to purchase fractional interests for cash. Such a repurchase has the effect of wholly terminating the equity interest of a shareholder whose total ownership is less than one full share. Liquidation of the cquity interest in this fashion results in discrimination among shareholders based on the size of individual holdings. Investors whose post-split holdings amount to one full slare or more maintain an ownership interest in the corporate assets and its goimg busimess. Any repurchase as applied to them merely adjusts downward, rather than negates, that proprietary interest. Shareholders whose total holdings are less than a full post-split share, on the other hand, are compelled to take a cash payment as a substitute for an ownership interest. If the bulk of the minority is eliminated, the practical result is a distribution in kind of the main assets of the going corporation to the majority stockholders.

Nevertheless, the repurchase of fractional shares pursuant to a reverse split has been analogized to the short-form merger as a statutorily authorized manner of terminating shareholder equity. ${ }^{48}$

Fed. Sec. L. REp. I 91,288 (Baltimore City Cir. Ct., Md. May 16, 1963). However, in Kaufmann v. Lawrence, 386 F. Supp. 12 (S.D.N.Y. 1974), the court refused to enjoin a tender offer, the purpose of which was to allow the issuer to escape federal regulation by "going private." While the court found that the scheme raised "serious questions concerning protection of the public interest," it nevertheless declared that: "there is nothing invalid per se in a corporate effort to free itself from federal regulations, provided the means and methods used to effectuate that objective are allowable under the law." Id. at 17.

43. Teschner v. Chicago Title \& Trust Co., 59 Ill. 2 d 452, -, 322 N.E.2d 54, 56 (1974). 
Such a comparison is overbroad and unwarranted. The elimination of minority shareholders incident to a cash merger may be objectionable in a nonpredatory transaction, i.e., a nnerger nnotivated by legitimate business reasons. ${ }^{44}$ However, courts have demonstrated an increasing hostility to cash mergers undertaken primarily for the purpose of freezing out minority shareholders. ${ }^{45}$ Moreover, in the context of voluntary dissolutions, courts have invalidated nonratable distributions in which the majority received the main assets and the going business in kind, with the minority relegated to taking the cash value of their proportionate share of the total assets. ${ }^{46}$ This trend is fully applicable to the transaction being discussed here, particularly since no statute expressly authorizes the repurchase of fractional shares for the purpose of terminating the equity interest of a shareholder. ${ }^{47}$ If the statutory authorization of fractional share repurchases is indeed intended only to facilitate administrative functions, that power should not be employed for the purpose of changing the status of the small investor from shareholder to creditor, except where that change is truly incidental to a legitimate transaction mandated by an independent business purpose. If the management is intent on acquiring minority shares it should pursue instead the less objectionable alternative of directly purchasing the shares in a voluntary negotiated transaction or by tender offer, and should refrain from using fractional share repurchase statutes to indirectly accoinphish the same result.

A busimess purpose for the creation of fractional interests sufficient to outweigh the shareholders' interest in liquidity of investment would not necessarily justify a repurchase for cash. The corporation may rid itself of substantially all administrative burdens incident to fractional shares merely through the issuance of scrip. As a prerequisite to a fractional share repurchase which may result in the elimination of the

44. See, e.g., Grimes v. Donaldson, Lufkin \& Jenrette, Inc., [1974-1975 Transfer Binder] CCH FED. SEC. L. REP. \ 94,722 (N.D. Fla. July 15, 1974).

45. See Bryan v. Brock \& Blevins Co., 490 F.2d 563 (5th Cir.), cert. denied, 419 U.S. 844 (1974) (short-form merger); Albright v. Bergendahl, [1974-1975 Transfer Binder] CCH FED. SEC. L. REP. I 94,997 (D. Utah Sept. 5, 1974) (long-form merger); Levine v. Biddle Sawyer Corp., 383 F. Supp. 618 (S.D.N.Y. 1974) (short-form merger). But see Green v. Santa Fe Industries, Inc., 391 F. Supp. 849 (S.D.N.Y. 1975) (shortform merger).

46. See, e.g., Lebold v. Inland Steel Co., 125 F.2d 369 (7th Cir.), cert. denied, 316 U.S. 675 (1941); In re Security Finance Co., 49 Cal. 2d 370, 317 P.2d 1 (1957); Zimmerman v. Tide Water Assoc. Oil Co., 61 Cal. App. 2d 585, 143 P.2d 409 (4th Dist. 1943); In re San Joaquin Light \& Power Corp., 52 Cal. App. 2d 814, 127 P.2d 29 (4th Dist. 1942).

47. An exception to the generally unrestricted statutory language is ARR. STAT. ANN. $\$ 64-105$ (F) (1965), which invalidates issuer repurchases of full or fractional shares designed to effect a fraudulent or unfair liquidation, or a fraudulent, unfair, or improper discrimination between shareholders. 
entire equity interest of any shareholder, the corporation should therefore be required to demonstrate that a cash liquidation serves a compelling business purpose which could not be achieved through the less discriminatory option of a scrip issuance. ${ }^{48}$ This business purpose test is consistent with decisions in California and other jurisdictions which require such a showing to justify actions by a fiduciary which unduly disadvantage the minority. ${ }^{49}$

48. A freeze out transaction may be justifiable under the business purpose test if the advantage gained by the corporation, in view of the injury inflicted upon the terminated minority shareholder, is indeed compelling. A business purpose may justify the elimination of a minority stockholder who attempts to exact improper concessions from the majority by the exercise of a vested veto power over proposed corporate action which generally would be of benefit to all other shareholders. See, e.g., Matteson v. Ziebarth, 40 Wash. 2d 286, 242 P.2d 1025 (1952). Similarly, a freeze out may arguably be legitimated where the terminated party exercises an effective veto power over corporate activities by refusing to designate a Rule 146 (17 C.F.R. $\$ 230.146$ (1975)) investment representative where the corporation proposes to enter into a transaction in which securities are to be issued in rehiance on that rule. In Grimes v. Donaldson, Lufkin \& Jenrette, Inc., [1974-1975 Transfer Binder] CCH FED. SEc. L. REP. II 94,722 (N.D. Fla. July 15,1974$)$, the court accepted the elimination of accounting and legal costs associated with public ownership as a sufficient business purpose to justify large scale shareholder termination. But see Albright v. Bergendahl, [1974-1975 Transfer Binder] CCH Fed. SEC. L. REP. If 94,997 (D. Utah Sept. 5, 1974). The result condoned in Grimes trivializes the business purpose test and fails to take into account whether the benefit to the corporation adequately compensates for the injury to the terminated minority shareholder.

Such an analysis was not undertaken in Teschner because, as the court declared, "[t]he plaintiff did not allege or show any improper purpose on the part of the defendants." 59 Ill. $2 \mathrm{~d}$ at,- 322 N.E.2d at 58 . Placing the burden on the plaintiff to demonstrate an improper purpose for a facially discriminatory transaction entirely overlooks a ratability analysis. Compare the above-quoted language from Teschner with Albright v. Bergendahl, [1974-1975 Transfer Binder] CCH FED. SEc. L. REP. If 94,997 (D. Utah Sept. 5, 1974), involving a freeze out merger of a publicly held company with a newlycreated subsidiary controlled entirely by insiders of the public company. In entering summary judgment enjoining the inerger, the court stated with regard to the existence and burden of deinonstrating a legitimate business purpose:

[G]iven the facts and the circumstances, and, in particular, the absolute doinmance and control of these defendants of and over International Services Industries. Inc. and the duties to these defendants [citation omitted] the plaintiff does not have the duty of negating a "legitimate corporate purpose."

Id. at 97,453 .

49. See, e.g., Jones v. H. F. Ahmanson \& Co., 1 Cal. 3d 93, 114, 460 P.2d 464, 476, 81 Cal. Rptr. 592, 604 (1969); cf. Case v. New York Cent. R.R., 15 N.Y.2d 150, 204 N.E.2d 643, 256 N.Y.S.2d 607 (1965). Other courts have applied a business purpose test, but without an imquiry into the sufficiency of the purpose in comparison to the harm inflicted on the affected shareholders. See, e.g., Bryan v. Brock \& Blevins Co., 490 F.2d 563 (5th Cir.), cert. denied, 419 U.S. 844 (1974); Albright v. Bergendahl, [1974-1975 Transfer Binder] CCH FEn. SEC. L. REP. ๆ 94,997 (D. Utah Sept. 5, 1974); Biltmore Motor Corp. v. Roque, 291 So. 2d 114 (Fla. Dist. Ct. App. 1974); Browning v. C \& C Plywood Corp., 248 Ore. 574, 434 P.2d 339 (1967). See also Vorenberg, Exclusiveness of the Dissenting Stockholder's Appraisal Right, 77 HARv. L. REv. 1189, 
In those instances in which the corporation does attempt to demonstrate a busmess purpose, courts should also closely scrutinize the quality of the proffered justification. Not all alleged business purposes may be sufficiently compelling to justify the oppression visited on the minority in a particular transaction. Accordingly, courts which view the business purpose test as an all-or-nothing proposition are less than fully protective of both minority and corporate interests. For example, any transaction which results in the termination of any number of minority shareholders will by definition achieve operating economies for the corporation, and any publicly held corporation which succeeds in "going private" will clearly be spared the financial costs of comphiance with SEC requirements. However, the board of directors of such a corporation should not thereby be afforded carte blanche to run roughshod over the interests of the minority merely by procuring these tangible benefits for the corporation. Courts which condone oppressive acts without mquiry into the quantum and quality of the alleged legitimization thus trivialize both the concept of fiduciary responsibility and the intended rigor of the busmess purpose test. ${ }^{50}$

A more satisfying approach to the concept of a business purpose for nonratable treatment focuses on the fairness of the transaction in terms of the competing minority and corporate interests. Such an approach eschews the threshold logic of the all-or-none view, and instead utilizes a shding scale whereby corporate benefits flowing from the transactions are compared with the degree of oppression inflicted on the minority. Only in those instances in which the quality of corporate benefits rises above the disadvantage to the minority will a business purpose be sufficiently "coinpelling" to warrant judicial vindication. $^{\text {.1 }}$

In absence of a compelling busmess purpose, the preferable alternative to a cash repurchase of fractional shares, in terms of ratability, is the issuance of scrip or warrants. ${ }^{52}$ Admittedly, the use of scrip does impose a discriminatory burden on soine shareholders to the exclusion of others. For example, to the extent of his scrip holdings, a shareholder is deprived of substantive shareholder rights. In the case of the stockholder whose total share interest is less than a full share, this deprivation is absolute. Moreover, only scrip holders must

1204.05 (1964); Note, Freezing Out Minority Shareholders, 74 HARv. L. Rev. 1630, $1646-47$ (1961). For a discussion of a variable approach to the business purpose test, see text accompanying notes 50-51 infra.

50. See, e.g., Grimes v. Donaldson, Lufkin \& Jenrette, Inc., [1974-1975 Transfer Binder] CCH Fed. SEC. L. ReP. \{f 94,722 (N.D. Fla. July 15, 1974).

51. See, e.g., Case v. New York Cent. R.R., 15 N.Y.2d 150, 204 N.E.2d 643, 256 N.Y.S.2d 607 (1965). See also Note, 57 VA. L. Rev. 1223, 1235-37 (1971).

52. See text accompanying note 17 supra. 
take some affirmative action, i.e., aggregation, to preserve a proportionate equity interest and reinstate these substantive shareholder rights. Neither burden falls upon the shareholders whose holdings amount to exactly full shares. Despite these disparities, the use of scrip adequately compromises the competing interests of the minority and the corporation. The issuer may bypass the administrative difficulties of a fractional share certificate issue, and corporate books are cleared of the fractional interests. Unlike the shareholder whose fractional equity interest is liquidated by the cash repurchase, the scrip holder is afforded an opportunity to preserve a proportionate equity participation in the corporation. Assuming that the board does not subsequently cause the corporation to purchase outstanding scrip and that the duration of the scrip is not limited, no potential arises for one group of stockholders to enjoy an ownership interest in the assets and business of the corporation to the exclusion of another shareholder group..$^{53}$

The issuance of scrip, however, can also occur in a manner that results in nonratable treatment to minority shareholders. In most jurisdiction scrip does not ensure preservation of the scripholder's proprietary interest in the corporation. The corporation may limit the duration of the scrip or sell the shares represented by the scrip, paying the cash received to the scripholder in exchange for his interest. ${ }^{54}$ Such provisions ultimately condone the same type of objectionable nonratable treatment which exists under a direct cash purchase of fractional shares. In issuing scrip, the corporation has vindicated its administrative interest in avoiding the use of fractional shares. Simce no substantive shareholder rights may be exercised through scrip, there is no justification for furthering this corporate administrative interest by voiding nonaggregated scrip. Nor is voiding or cashing out non-aggregated scrip a necessary incentive toward aggregation to a full share interest, since such an incentive is already provided by the interim suspension of dividend and voting rights to the extent that a share interest is represented by outstanding scrip. Absent a compelling business purpose for this treatment of outstanding scrip, the shareholder discrimination which flows froin voiding or a compulsory repurchase of scrip conflicts with the fiduciary norm of ratability.

\section{Valuation of Fractional Shares in the Repurchase Transaction}

Where the corporation fails to demonstrate a business necessity for termination of shareholder interests, the transaction cannot be justified

53. The use of scrip does not obviate further discrimination that can arise in freeze out transactions. Fiduciary responsibilities remain in formulating exchange ratios and in preserving the liquidity of the share investment.

54. See note 18 supra. 
by assurances that a "fair" price will be paid by the corporation for the repurchased fractional interests. ${ }^{55}$ There may be some circumstances, however, which require a mandatory cash buy-out of those shareholders loolding fractional interests. ${ }^{56}$ In sucl instances, i.e., where liquidity or shareholder status is affected, the selling shareliolders should be allowed a right of appraisal.

Under existing law, the board unilaterally specifies the amount of cash payable in excliange for, or in lieu of, fractional shares. ${ }^{57}$ Shareliolders, in their capacity as such, lave no formal imput into the actual valuation of fractional interests. Statutes limit the role of shareliolders to approval or disapproval of the certificate amendment providing for the reverse split or reclassification. No statute requires that the amendinent specify in addition the value to be ascribed fractional shares, or that the value be determined prior to the shareholder vote on the amendment. Typically, statutes require only that the valuation shall be the fair value at the time that the fractional interest is created. ${ }^{58}$ While the shareholder vote may serve as an internal check on manageinent discretion imsofar as the decision to undertake a reverse stock split, it is unlikely to be an effective control over the power of the directors to undervalue fractional shares. In fact, even if a vote were allowed, it would be of little value where insiders control a majority of the voting shares. In that situation the board may propose the split and undervalue fractional shares to the extent reasonable pessimism will allow. Negative votes by the victimized outsiders will be superfluous. ${ }^{59}$

55. The timing of an objection may be critical in this regard. For example, in Kellogg v. Georgia-Pacific Paper Corp., 227 F. Supp. 719 (W.D. Ark. 1964), the court implied that appraisal might be plaintiff's only remedy for an illegal freeze out dissolution, because disentangleinent of the corporate sale of assets causes a greater harm to the purchaser than the gain which would inure to the complainant. Courts should not find themselves so constrained in the reverse split and repurchase, since there is a readily fashioned remedy: issuance of shares to the terminated stockholders.

56. See note 48 supra.

57. See, e.g., Dez. Gen. Corp. Law $\$ 155$ (1974); Ilz. Ann. Stat. ch. 32, § 157.22 (Smith-Hurd 1970); N.Y. Bus. CoRP. LAw $\$ 509$ (McKinney 1963); ABA MODEL Bus. CoRp. ACT $\$ 24$ (1969 rev.). In Nevada and Ohio, the value may be set in the articles or, if not stated therein, as determined by the board. NEv. REV. StaT. $\S 78.205$ (1973); OHIO REV. CoDE ANN. \$ 1701.24 (Page 1964).

Only two jurisdictions expressly restrict the board's discretion in valuing fractional shares by providing that a sale of the shares lield in reserve for the fractional scrip issued must be accomplislied in a "fair and equitable" manner. N.C. GEN. STAT. $\$$ 55-58 (1975); Tenn. Code ANN. $\$ 48-510$ (Supp. 1974).

58. See, e.g., DeL. GEN. CORP. LAW $\$ 155$ (1974); N.Y. Bus. CoRp. LAW $\$ 509$ (McKinney 1963); ABA Model Bus. CoRP. ACT \$ 24 (1969 rev.).

59. The shareholder vote of the minority may be unable to block a certificate amendment regardless of the valuation of fractional shares offered by the board, particularly where there is no statutory provision for appraisal of dissenting sliares. However, 
In some freeze out transactions, notably mergers, the minority shareholder cannot be compelled to accept a unilateral valuation of shares by the board and can instead dissent and resort to appraisal proceedings for an impartial determination of share value. ${ }^{60}$ No such election is available to dissatisfied shareholders in a reverse stock split since appraisal rights are generally not triggered by a certificate amendment authorizing a reverse split or reclassification. ${ }^{01}$ Consequently in a cash liquidation transaction, a shareholder who does not "round up" is compelled to sell a fractional interest to the issuer for a cash value determined solely and conclusively by the board, rather than as the result of negotiation at arm's length between a willing buyer and a willing seller.

The absence of a proceeding of recourse such as appraisal, whereby a shareholder's economic interests may be protected against arbitrary or self-interested undervaluation by management, might suggest increased legislative and judicial vigilance to safeguard minority interests. Under many current fractional share statutes, lowever, valuation may be characterized as a inatter of internal corporate management governed by the business judgment standard of review. On the face of the transaction, no undue advantage is gamed by msiders which would trigger the judicial scrutiny typical in instances of self-dealing.

when appraisal is offered, it may be argued that the availability of appraisal serves as an internal check on undervaluation of fractional shares, even where the board is assured of majority approval of the certificate amendment. If undervaluation is so plain as to induce a large portion of the minority to dissent, the aggregate cash demand on the corporation could be significant. It has been suggested that the severity of this cash drain could induce the board to restructure its proposals in a manner more appealing to the class of potential dissenters. See Folk, De Facto Mergers in Delaware: Hariton v. Arco Electronics, Inc., 49 VA. L. REv. 1261, 1293 (1963); see also Manning, The Shareholder's Appraisal Remedy: An Essay for Frank Coker, 72 YALE L.J. 223, $234-35$ (1962). But see Eisenberg, supra note 36, at 74.

60. Any general discussion of appraisal rights is subject to various qualifications on the dissenter's rights imposed in some jurisdictions. Several states preclude the appraisal right for shares registered on a national securities exchange, see, e.g., DEL. GEN. CoRp. LAW \& 262(k) (1974); Fla. Stat. ANN. \$ 608.23 (1969); GA. CODE ANN. § 22 1201 (1969); Ind. Stat. ANN. \& 25-240 (Burns 1972); Kan. Stat. ANN. \& 17-6712 (1974); ABA MODEL Bus. CoRP. ACr $\$ 80$ (1969 rev.); and shares held by 2000 or more shareholders, see, e.g., the Delaware, Florida, and Kansas statutes cited supra. For a compilation of other appraisal limitations, see 2 ABA MODEL Bus. CoRP. ACT ANN. 438 (1971), and ABA Model Bus. Corp. ACT ANN. 365-66 (Supp. 1973).

61. Some jurisdictions do confer hinited appraisal rights where specified types of certificate aniendments will substantially prejudice a class of stockholders. See, e.g., Conn. Gen. Stat. ANN. \& 33-373 (1958); Idaho Gen. LaW ANN. \$ 30-150 (1967); Mo. Ann. Code art. 23, \& 10 (1973); Mass. Gen. Law ANN. ch. 156B, \& 76 (1970); Mo. ANN. STAT. \& 351.090 (1966); N.Y. Bus. CoRP. LAW $\$ 806(b)(6)$ (McKinney Supp. 1974); N.C. Bus. CoRp. Act \& 55-101 (Supp. 1973); OHто Rev. Code ANN. \& 1701.74 (Page 1964); Okta. Stat. AnN. tit. 18, \$ 1.157 (1951); Pa. Stat. ANN. tit. 15 , 1810 (1967); TenN. Code ANN. $\$ 48-909$ (2) (1974). 
Deference might therefore be given to management's value determination, absent fraud or bad faith. Indeed, some statutes permitting cash payments for fractional shares accord fimal and conclusive effect, absent a showing of fraud, to the board's valuation of fractional shares, and can be interpreted as expressly incorporating the business judgment standard. ${ }^{62}$ Such statutes appear to preclude judicial inquiry into the fairness of the board's valuation. The valuation is rendered prima facie valid, and the burden is imiposed on the dissenting shareholder to produce elusive evidence of a violation of fiduciary duty or actual fraud, rather than merely a mistaken economic judgment by the board.

Although a deferential standard of review for fractional share valuation inay be appropriate in some instances, the business judgment standard is clearly inappropriate in a transaction which generates a conflict of interest for management. Freezing out fractional shareholders through a cash repurchase is such a transaction. To the extent that minority interests are eliminated or reduced, the proportionate ownership interest of insiders is likely to be enhanced. Consequently inanagement, as the dominant resulting ownership interest in the enterprise, is likely to be disabled from making an imipartial, arm's length assessment of share value. Management will instead tend to pessimistically assess the value of fractional shares, retaining primarily for itself assets which would otherwise be paid to liquidated fractional stockholders. ${ }^{63}$

In a freeze out transaction, shareholders should be entitled to an informed, arm's length valuation of their shares. Since the business judgment of the board in this regard is self-interested and therefore suspect, an inipartial and external valuation is necessary to protect shareholders economically, as well as to insulate the transaction from subsequent attack as a conflict of interest. Fortunately, case law suggests that the board's business judgment in assessing share value in a freeze out transaction, without further external control, may be insufficient to insulate the transaction from economic challenge on fiduciary grounds. ${ }^{04}$

62. E.g., GA. CoDE ANN. $\$ 22-509$ (b) (1969) (absent bad faith, all acts of board pursuant to this subsection [cash payment] shall be conclusive); VA. CODE ANN. $\$ 13.1$ 21 (Supp. 1975) (value determination by board, absent fraud, shall be final).

63. The same conflict of interest arises in the context of a parent-subsidiary merger where minority shares in the subsidiary are liquidated by a cash payment from the parent. The parent corporation, due to its self-interested position as the sole resulting owner in an upstream merger, is likely to pessimistically value the assets and going business of the subsidiary, thereby undervaluing subsidiary shares. See Brudney \& Chirelstem, Fair Shares in Corporate Mergers and Takeovers, 88 HARv. L. REv. 297, 298 (1974).

64. See Kellogg v. Georgia-Pacific Paper Corp., 227 F. Supp. 719 (W.D. Ark. 1964) (invalidating a sale of assets and dissolution eliminating minority shareholders 
Various options are available which help to ensure a fair and impartial appraisal of share value in a freeze out transaction. The recommendation of share value by a qualified and disinterested party has been a factor in several cases upholding freeze out transactions in publicly held companies. In Scott v. Multi-Amp Corp. ${ }^{\circ 5}$ and Richland v. Crandall, ${ }^{68}$ substantially all the assets of a public corporation were sold to companies controlled by corporate insiders. Subsequently the public companies were dissolved, and the public shareholders were compelled to take cash for their shares in the hquidation distribution. Plaintiffs in both cases unsuccessfully challenged, inter alia, the economic fairness of the board's valuation of the liquidated public corporation on a per share basis. In Scott, the court noted among the indicia of a fair valuation by the board that an investment banking firm had been retained to render an independent appraisal and written opimion on the fairness of the per share price proposed by the board. ${ }^{67}$ An appraisal and opmion letter rendered for the purchasing group in Richland by an underwriter-investment banker that confirmed the fairness of the proposed share valuation was empliasized by that court as one inanifestation of economic fairness. ${ }^{88}$ In Grimes $v$. Donaldson, Lufkin \& Jenrette, Inc., ${ }^{69}$ a public company freeze out was accomplished through a merger with a newly-incorporated shell subsidiary controlled by the dominant stockholder of the public corporation. The court in Grimes rejected plaintiff-shareholder's claim of unfair valuation of minority shares, noting that the basis for the board's value determination was an independent appraisal of share value obtained from an experienced investment banking firm. ${ }^{70}$

in which minority shares were valued unilaterally by the majority shareholder). In its discussion of the per share valuation to which the minority would be entitled on a proper liquidation, the court stated that "at the very least, [minority shareholders] are entitled to the fair value of their stock, determined impartially, and are not required to accept a value fixed by the majority stockholders." Id. at 725 .

65. 386 F. Supp. 44 (D.N.J. 1974).

66. 262 F. Supp. 538 (S.D.N.Y. 1967).

67. 386 F. Supp. at $59-60,68$.

68. 262 F. Supp. at 548-49.

69. [1974-1975 Transfer Binder] CCH FED. SEc. L. REp. đ 94,722 (N.D. Fla. July 15,1974 ).

70. Id. at $96,388,96,391$.

Another means of insuring economic fairness, though generally not applicable to the circumstances of a reverse split, is indieated in Grimes and Richland, where the final share price was influenced by extensive negotiation by the board with a substantial outside stockholder whose shares would be cashed out in the transaction. While not truly an arm's length negotiation since the sale of shares was compulsory, the result may be to enhance the initially proposed share price for the benefit of all minority shares. See also Alcott v. Hyman, 40 Del. Ch. 449, 184 A.2d 90 (Del. Ch. 1962), aff'd, 42 Del. Ch. 233, 208 A.2d 501 (1965). In Alcott, public shareholders who were frozen out through a sale of assets and liquidation complained of economic unfairness in the 
Although resort by the board to an impartial valuation may bolster the fairness of the board's economic assessment, the status of the external appraiser as an institutionally imdependent, economically disinterested, and qualified party is a question of fact in each instance. Such a status inay be negated by circumstances indicating, for example, that the appraiser has had or will have a substantial course of dealing with the corporation, has underwritten or will underwrite a securities offering by the issuer, or has limitations or recommendations imposed upon the scope of its appraisal by the corporation.

In the event the freeze out is essentially a two-step transaction, as in Teschner, it may be possible for management to resort to a second mode of insulating valuation. In Teschner, the reverse split and involuntary repurchase followed a voluntary casli exchange offer by the dominant stockholder at a premium over the current inarket value. The subsequent valuation of fractional shares adopted the attractive per share price announced in the exchange offer. While the court in Teschner did not rule on the fairness of the fractional share value, the fact that the same price was offered in the cramdown transaction as was overwhelmingly accepted by other shareliolders in the previous exchange offer appears to enhance the fairness of the fractional share valuation. This method of assessment, lowever, is at best a poor surrogate for an informed, arm's length bargaining, and it is justifiable only on the assumption that full and fair disclosure is made in conjunction with the exchange offer. Moreover, management's ability to control the timing of the two transactions to correspond with a temporarily depressed share price, or an anticipated substantial imcrease in corporate earnings which is not yet ripe for disclosure, creates the possibility that the enterprise is currently worth more than the offering price and the pegged fractional share value might suggest. The resnlt may then be little better than the unilateral valuation envisaged in present statutes.

The third and most acceptable alternative would be to provide that appraisal rights are triggered by a certificate amendment authorizing a reverse stock spht or reclassification, where such action would either substantially impair the marketability of post-split shares ${ }^{71}$ or occasion a freeze out transaction with an implicit discrimination between shareholders. Some jurisdictions currently afford appraisal as the result of

valuation of their shares. In rejecting this claim, the court indicated that the share price was the culmination of extensive negotiation between a dominant stockholder of the old company and the group which controlled the new corporation, minority shareholders receiving the saine share price as the dominant shareholder had bargained for himself.

71. Recourse to appraisal could be available, under this standard, where the issuer's actions resulted in the involuntary delisting of corporate shares from a national securities exchange. 
specified certificate amendments, ${ }^{72}$ but none of these statutes expressly relate to the reverse stock split. While all minority shareholders could resort to appraisal in the event of impairment of marketability, only those shareliolders who are terminated require recourse to appraisal where marketability is not substantially impaired.

The grant of appraisal in the context of the reverse sphit would conceivably serve several desirable functions. First, it would afford the terminated stockholder the opportumity to reject the unilaterally formulated valuation of fractional share interests proposed by the board. Dissenting shareholders could instead resort to an impartial forum for an assessment of share value. Second, an appraisal proceeding would avoid the appraiser-shopping which is inevitable under the "independent appraiser" approach. ${ }^{73}$ Fimally, appraisal would ensure a surrogate market for post-split shares that would not be subject to manipulation by issuer actions and that would compensate for dechine in value where the hiquidity of the actual market has been impaired by the reverse split, the repurchase of fractional shares, or both. The availability of appraisal would not dispense with the fiduciary's duty to protect marketability. Presamably, appraisal would be a real option only where the corporation's actions are in conformity with the overlay of fiduciary obligations, or where the issuer justifies its deviation from those norms by demonstrating a sufficient business purpose for the discriminatory action.

\section{ConCLUSION}

Current corporate statutes do not adequately protect minority interests against involuntary termination of shareholder status through the reverse stock split and repurchase transaction. Even in those instances in which immediate elimination does not result, the expectations of the fractionalized stockholder regarding the liquidity and valuation of his investment are jeopardized by the unilateral and conclusive actions of the board of directors, in conjunction with majority shareholders.

The protections of the minority stockholder against oppression at the hands of the majority in this corporate transaction must be drawn from a rigorous application of common principles of fiduciary obligation and ratable shareholder treatment. Only when the need to completely terminate stockholder status by repurchase of fractional interests is

72. See note 61 supra.

73. Despite the existence of appraisal, the board may still obtain independent opinions of the fairness of the proposed price, since such insulating actions will bolster the reasonableness of the board's ultimate valuation. 
indeed "compelling," based on a fair balancing of the competing interests of the minority and majority, should courts countenance the use of this freeze out technique. A repurchase in compliance with the overlay of fiduciary limitations, however, may be justifiable, and in that context, legislatures should change present appraisal statutes so that such a drastic interference with shareholder expectations will trigger a mechanism for economic protection of minority shareholders. 